\title{
First studies showing high temephos resistance in Anopheles labranchiae (Diptera: Culicidae) from Tunisia
}

\author{
Ahmed Tabbabi, Jabeur Daaboub
}

Department of Hygiene and Environmental Protection, Ministry of Public Health, Tunis, Tunisia.

\begin{abstract}
Background: Despite the public health importance of Anopheles (An.) labranchiae, their resistance status to temephos insecticide has not, to our knowledge, been explored.

Objectives: The present study was carried out to determine the temephos resistance status of field populations of $A n$. labranchiae from Tunisia.

Methods: Six field populations of An. labranchiae were collected as larvae from breeding sites of Northern and Central Tunisia. All the tests were carried out according to the WHO method.

Results: Results reported that the majority of field populations showed low and medium resistance ratios $(6.2<$ RR $50<29.8)$ to temephos insecticide tested except for the strain \# 1 which had interestingly a very high resistance with RR50 of 624 never detected in Tunisia and North Africa even on other species of mosquitoes

Conclusion: The resistance ratios of this species were higher than recorded in other countries. Biochemical and molecular studies would be of great importance to identify the mechanisms involved in the recorded resistance to temephos.

Keywords: Anopheles labranchiae, temephos insecticide, Tunisia.

DOI: https://dx.doi.org/10.4314/ahs.v18i1.7

Cite as: Tabbabi A, Daaboub J. First studies showing high temephos resistance in Anopheles labranchiae (Diptera: Culicidae) from Tunisia. Afri Health Sci 2018;18(1): 41-47. bttps:// dx.doi.org/10.4314/ahs.v18i1.7
\end{abstract}

\section{Introduction}

In Tunisia, The last registered case of autochthonous malaria was reported in 1979. Since then a vector control involves killing the larvae of the main malaria vectors, An. labranchiae (Falleroni, 1926), through the judicious use of environmentally safe insecticides was reported to prevent re-establishment of malaria transmission and to control other vector borne diseases ${ }^{1-4}$. Mosquito control with the use of insecticides was faced with the challenges

\section{Corresponding author: \\ Ahmed Tabbabi, Department of Hygiene and \\ Environmental Protection, Ministry of Public Health, Tunis, Tunisia. Email: tabbabiahmed@gmail.com}

of insecticide resistance in malaria vectors, community refusal, their high cost, operational difficulties, and environmental concern. In view of this, integrated vector control strategies with the use of larvivorous fishes such as Gambusia ( $G$. affinis) as biological control agents were used in controlling mosquito breeding in different types of habitat places.

In Tunisia, an intensive control program was carried out in the framework of the National Program for the Eradication of Malaria during the $60 \mathrm{~s}$ and 70 s against malaria vectors mainly through the use of DDT. The pathology disappeared from the country since 1979. Since then, other insecticides including temephos organophosphate were used for prevention and control of vector-borne diseases $^{2-5}$. Two important organophosphate resistance mechanisms exhibited by insects are metabolic-based re- 
sistance ${ }^{3,5}$ including three groups of detoxifying enzymes: mono-oxygenases, esterases, and glutathione S-transferases and target site insensitivity including acethylcholinesterases resistance $\mathrm{e}^{3,5}$.

Therefore, periodic evaluation of insecticide susceptibility is a necessary part of good pest management practice. Despite the public health importance of An. labranchiae, their susceptibility tests to temephos have not, to our knowledge, been explored. A good understanding of their resistance status could improve vector control implementation through targeted strategies.

Temephos insecticide is considered by World Health Organization ${ }^{6}$ as a suitable and safe mosquito larvicide that can be used even in drinking water for controlling of the most mosquito vectors. The temephos discriminating dosage, established by WHO, for the genus Anopheles is $0.25 \mathrm{mg} / \mathrm{L}$. Afterward, it was stated locally for a limited number of species ${ }^{7}$. For $A n$. Hyrcanus, this dose was set at $0.025 \mathrm{mg} / \mathrm{L}$ and it was $0.625 \mathrm{mg} / \mathrm{L}$ for $A n$. sacharov that belongs to the same complex as An. labranchiae.

The present study was carried out to determine the teme- phos resistance status of field populations of An. labranchiae from Tunisia. This study will also serve as reference data which could be applied in countries around Mediterranean sea, particularly Morocco, Algeria, Italy, and France where An. labranchiae is present and could constitute a risk for malaria transmission ${ }^{8-11}$.

\section{Materials and methods}

\section{Mosquito strains and study areas}

Six field populations of An. labranchiae were collected as larvae from breeding sites of Northern and Central Tunisia (Figure 1). A sensitive strain was used as reference to compare the level of resistance with resistant strains. It should be noted that general characteristics of study areas including insecticides usage is given in Table 1. Data was collected according to the ministry of health and during individual interviews with the collection sites residents. The larvae were transferred to the laboratory in the original water. The larvae were putted directly in clean standing water in the laboratory and fed daily with ground food mixture. Larvae were used for bioassays and eggs were reared to larvae under laboratory conditions. Larvae from eggs were used for toxicological tests if the number of collected larvae was not enough.

\section{Table 1: Geographic origin of Tunisian populations of An. labranchiae, breeding site characteristics, and insecticide control}

\begin{tabular}{clcclc}
\hline Code & Governorate & $\begin{array}{c}\text { Breeding } \\
\text { sites }\end{array}$ & $\begin{array}{c}\text { Date of } \\
\text { collection }\end{array}$ & Mosquito control (used insecticides) & $\begin{array}{c}\text { Agricultural } \\
\text { pest control }\end{array}$ \\
\hline 1 & Ben Arous & Ditch & Oct. 2016 & Occasional (P,D) & Yes \\
2 & Ariana & River & Oct. 2016 & Rare $(C, P)$ & Yes \\
3 & Beja & Water pond & Nov. 2016 & None & Yes \\
4 & Jandouba & River & Nov. 2016 & Occasional (P) & Yes \\
5 & Kairouan & Ditch & Oct. 2016 & None & Yes \\
6 & Monastir & Water pond & Oct. 2016 & Rare $(C, F)$ & Yes \\
\hline
\end{tabular}

C : Chlorpyrifos ; F : Fenitrithion ; P : Permethrin ; D : Deltamethrin 


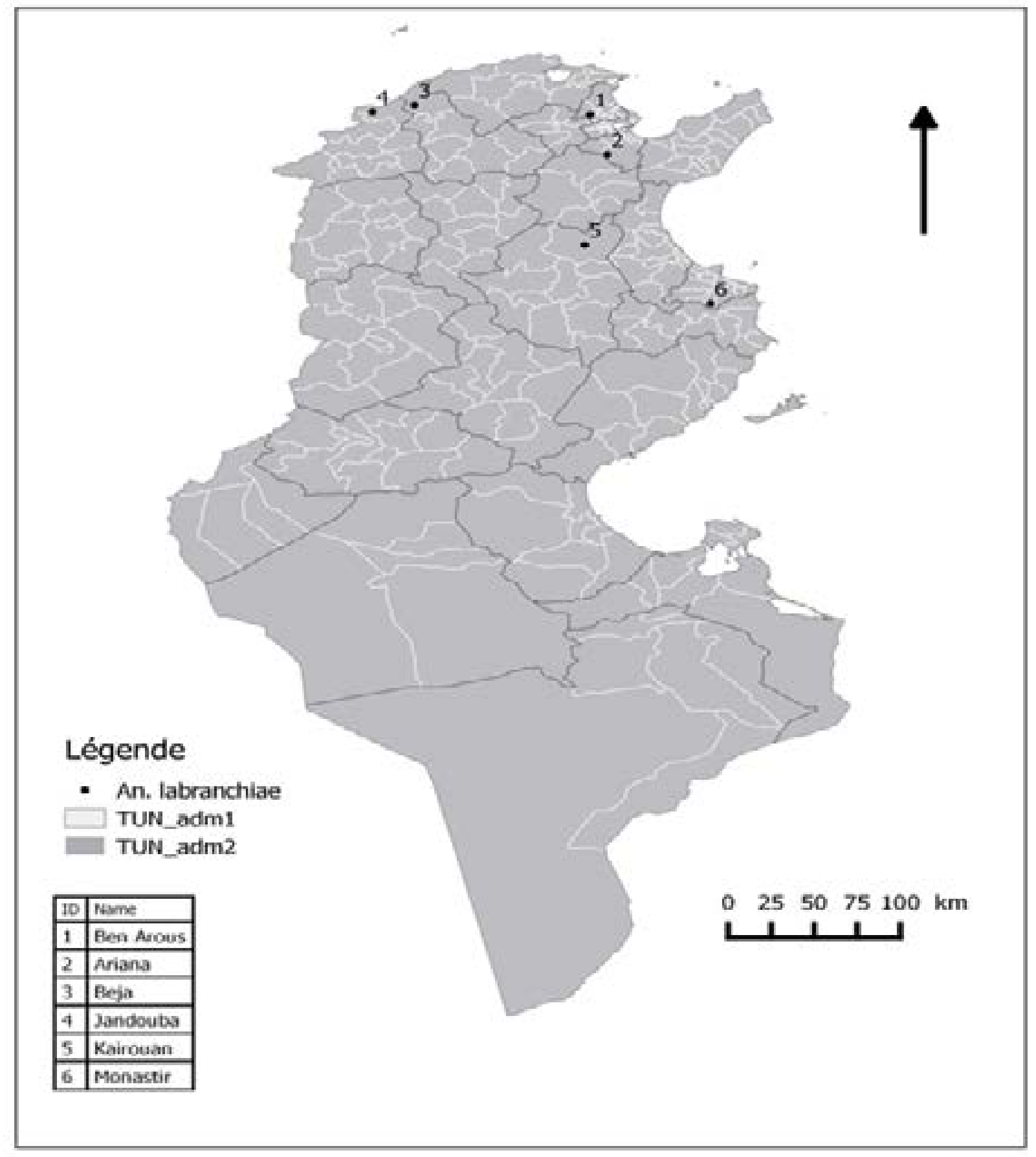

Figure 1: Geographic origin of Tunisian populations 


\section{Chemicals insecticides and synergists}

The insecticides tested were the organophosphates temephos (91\%o; American Cyanamid, Princeton, NJ), and the carbamate propoxur (997o; Mobay). Two synergists were used to help detect detoxification enzymes involved in resistance: S, S, S \{ributyl phosphorothioate (DEF), an esterase inhibitor, and piperonyl butoxide $(\mathrm{Pb})$, an inhibitor of mixed function oxidases.

\section{Resistance tests}

The susceptibility to temephos insecticide was carried out on late $3^{\text {rd }}$ or early $4^{\text {th }}$ instar larvae of the filed populations. Third- and fourth-instar larvae were morphologically identified using the standardized key for the mosquitoes of Mediterranean Africa ${ }^{12}$. The bioassays followed the recommended experimental protocol standardized by the $\mathrm{WHO}^{13}$. Five concentrations were used for each insecticide. Triplicate of 20 larvae were employed for each concentration and mortality was noted after 24 hours.
Triplicate of control were used and exposed to alcohol. The bioassay was cancelled if mortality exceeded $10 \%$.

\section{Data analysis}

We used log probit analysis of Raymond ${ }^{14}$, based on Finney ${ }^{15}$ which provides LCs, slope for each mortality line, parallelism between different mortality lines and resistance ratios with 95\% confidence intervals to analyze mortality data.

\section{Results}

\section{Insecticides resistance}

As showed in Table 2, the majority of field populations showed low and medium resistance ratios $(6.2<\mathrm{RR} 50<$ 29.8) to temephos insecticide tested except for the strain \# 1 which had interestingly a very high resistance with RR50 of 624 never detected in Tunisia and North Africa even on other species of mosquitoes. Slopes values of studied populations were compared with sensitive strain and showed lower heterogeneity.

Table 2: Temephos resistance characteristics of Tunisian An. labranchiae in presence and absence of synergists DEF and $\mathrm{Pb}$

\begin{tabular}{|c|c|c|c|c|c|c|c|c|c|c|c|c|c|}
\hline \multirow[b]{2}{*}{$\begin{array}{c}\text { Populatio } \\
n\end{array}$} & \multicolumn{3}{|c|}{ Temephos } & \multicolumn{5}{|c|}{ Temephos +DEF } & \multicolumn{5}{|c|}{ Temephos $+\mathrm{Pb}$} \\
\hline & $\begin{array}{c}\mathrm{LC}_{50} \\
\text { in } \\
\mu \mathrm{g} / \mathrm{l} \\
\text { (a) }\end{array}$ & $\begin{array}{l}\text { Slope } \\
\pm \text { SE }\end{array}$ & $\begin{array}{c}\mathbf{R R}_{50} \\
\text { (a) }\end{array}$ & $\begin{array}{c}\mathrm{LC}_{50} \text { in } \\
\mu \mathrm{g} / \mathrm{l} \\
\text { (a) }\end{array}$ & $\begin{array}{l}\text { Slope } \\
\pm \mathrm{SE}\end{array}$ & $\begin{array}{l}\mathbf{R R}_{50} \\
\text { (a) }\end{array}$ & $\begin{array}{l}\mathrm{SR}_{50} \\
\text { (a) }\end{array}$ & RSR & $\begin{array}{c}\mathrm{LC}_{50} \text { in } \\
\mu \mathrm{g} / \mathrm{l} \\
\text { (a) }\end{array}$ & $\begin{array}{l}\text { Slope } \\
\pm \text { SE }\end{array}$ & $\begin{array}{l}\mathbf{R R}_{50} \\
\text { (a) }\end{array}$ & $\begin{array}{l}\mathrm{SR}_{50} \\
\text { (a) }\end{array}$ & $\begin{array}{c}\mathbf{R S} \\
\mathbf{R}\end{array}$ \\
\hline $\begin{array}{l}\text { Sensit } \\
\text { ive } \\
\text { strain }\end{array}$ & $\begin{array}{c}0.9 \\
(0.1-1.2)\end{array}$ & $\begin{array}{c}2.18 \\
\pm 0.31\end{array}$ & - & $\begin{array}{c}0.41 \\
(0.22- \\
0.57)\end{array}$ & $\begin{array}{c}3.78 \\
\pm 0.59\end{array}$ & - & $\begin{array}{c}2.1 \\
(1.8-3.0)\end{array}$ & - & $\begin{array}{c}0.56 \\
(0.3-1.1)\end{array}$ & $\begin{array}{c}0.88 \\
\pm 0.17\end{array}$ & - & $\begin{array}{c}1.60 \\
(1.33- \\
2.12)\end{array}$ & - \\
\hline 1-Ben & 561.6 & 2.395 & 624 & 120.49 & 2.45 & 263.87 & 4.66 & 2.3 & 489.8 & $1.99 *$ & 874.64 & 1.14 & 0.71 \\
\hline Arous & $\begin{array}{c}(480.4- \\
621.8)\end{array}$ & \pm 0.28 & $\begin{array}{c}(595.5- \\
659.4)\end{array}$ & $\begin{array}{l}(114- \\
135.2)\end{array}$ & \pm 0.45 & $\begin{array}{l}(222.5- \\
285.4)\end{array}$ & $\begin{array}{c}(6.18- \\
10.3)\end{array}$ & 6 & $\begin{array}{c}(401.1- \\
590.4)\end{array}$ & \pm 0.33 & $\begin{array}{c}(799.6- \\
320.9)\end{array}$ & $\begin{array}{c}(0.12- \\
1.40)\end{array}$ & \\
\hline 2- & 9.2 & $3.58 *$ & 10.2 & 7.2 & 1.18 & 17.5 & 1.2 & 0.5 & 10.3 & 3.01 & 18.39 & 0.89 & 0.55 \\
\hline $\begin{array}{c}\text { Arian } \\
\mathbf{a}\end{array}$ & $\begin{array}{l}(7.4- \\
12.3)\end{array}$ & \pm 0.16 & $\begin{array}{l}(8.7- \\
16.3)\end{array}$ & $(5.7-9.3)$ & \pm 0.22 & $\begin{array}{c}(13.5- \\
18.7)\end{array}$ & $(0.9-2.4)$ & 8 & $(8.7-12.9)$ & \pm 0.21 & $\begin{array}{c}(17.4- \\
19.4)\end{array}$ & $\begin{array}{c}(0.67- \\
1.35)\end{array}$ & \\
\hline 3-Веја & $\begin{array}{c}5.6 \\
(4.1-7.0)\end{array}$ & $\begin{array}{l}1.55 \\
\pm 0.05\end{array}$ & $\begin{array}{c}6.2 \\
(3.0-9.7)\end{array}$ & $\begin{array}{c}4.3 \\
(3.9-5.1)\end{array}$ & $\begin{array}{c}1.97 \\
\pm 0.23\end{array}$ & $\begin{array}{l}10.4 \\
(8.7- \\
13.0)\end{array}$ & $\begin{array}{c}1.3 \\
(0.8-1.8)\end{array}$ & $\begin{array}{c}0.5 \\
9\end{array}$ & $\begin{array}{c}6.9 \\
(5.19-8.12)\end{array}$ & $\begin{array}{c}1.08 \\
\pm 0.24\end{array}$ & $\begin{array}{c}12.32 \\
(11.52- \\
13.52)\end{array}$ & $\begin{array}{c}0.81 \\
(0.57- \\
2.1)\end{array}$ & 0.50 \\
\hline 4- & 22.9 & 2.74 & 25.4 & 5.76 & 0.90 & 14.0 & 3.9 & 1.8 & 12.9 & $1.59 *$ & 23.03 & 1.77 & 1.1 \\
\hline $\begin{array}{c}\text { Jando } \\
\text { uba }\end{array}$ & $\begin{array}{l}(18.3- \\
26.8)\end{array}$ & \pm 0.35 & $\begin{array}{l}(19.8- \\
28.4)\end{array}$ & $\begin{array}{c}(4.22- \\
7.67)\end{array}$ & \pm 0.18 & $\begin{array}{c}(11.9- \\
17.4)\end{array}$ & $\begin{array}{l}(2.35- \\
4.05)\end{array}$ & 1 & $(10.4-14.6)$ & \pm 0.20 & $\begin{array}{c}(22.6- \\
24.9)\end{array}$ & $\begin{array}{l}(0.98- \\
2.7)\end{array}$ & \\
\hline $5-$ & 12.4 & $2.11 *$ & 13.7 & 10.2 & 1.80 & 24.8 & 1.2 & 0.5 & 15.3 & 3.12 & 27.32 & 0.81 & 0.50 \\
\hline $\begin{array}{c}\text { Kairo } \\
\text { uan }\end{array}$ & $\begin{array}{l}(8.2- \\
14.3)\end{array}$ & \pm 0.22 & $\begin{array}{l}(10.5- \\
22.2)\end{array}$ & $\begin{array}{l}(8.2- \\
11.9)\end{array}$ & \pm 0.13 & $\begin{array}{l}(20.5- \\
28.7)\end{array}$ & $(1.9-2.7)$ & 5 & $(12.4-18.7)$ & \pm 0.27 & $\begin{array}{c}(25.5- \\
33.5)\end{array}$ & $\begin{array}{c}(0.55- \\
1.44)\end{array}$ & \\
\hline $\begin{array}{c}\text { 6- } \\
\text { Mona } \\
\text { stir }\end{array}$ & $\begin{array}{r}13.2 \\
(10.4- \\
16.5)\end{array}$ & $\begin{array}{l}2.59 * \\
\pm 0.29\end{array}$ & $\begin{array}{c}14.6 \\
(11.9- \\
18.2)\end{array}$ & $\begin{array}{c}0.9 \\
(0.77- \\
1.3)\end{array}$ & $\begin{array}{c}1.98 \\
\pm 0.34\end{array}$ & $\begin{array}{c}2.2 \\
(1.5-4.7)\end{array}$ & $\begin{array}{c}14.6 \\
(13.9- \\
15.6)\end{array}$ & $\begin{array}{c}6.6 \\
3\end{array}$ & $\begin{array}{c}8.3 \\
(5.7-10.9)\end{array}$ & $\begin{array}{c}3.45 \\
\pm 0.33\end{array}$ & $\begin{array}{c}14.82 \\
(13.3- \\
16.2)\end{array}$ & $\begin{array}{r}1.59 \\
(0.99- \\
1.98)\end{array}$ & 0.98 \\
\hline
\end{tabular}

a), $95 \% \mathrm{CI} ; *$ The log dose-probit mortality response is parallel to that of sensitive strain

$\mathrm{RR}_{50}$, resistance ratio at $\mathrm{LC}_{50}\left(\mathrm{RR}_{50}=\mathrm{LC}_{50}\right.$ of the population considered/LC $\mathrm{L}_{50}$ of sensitive strain); $\mathrm{SR}_{50}$, synergism ratio (LC $\mathrm{L}_{50}$ observed in absence of synergist/LC $\mathrm{C}_{50}$ observed in presence of ;ynergist). RR and SR considered significant $(\mathrm{P}<0.05)$ if their $95 \% \mathrm{CI}$ did not include the value 1 ; RSR, relative synergism ratio (RR for insecticide alone / RR for insecticide plus synergist). 


\section{Synergism tests}

Our results of bioassays with synergists (Table 2) showed that the synergism ratio (SR) in all $A n$. labranchiae populations tested using DEF was low $(\mathrm{SR}<4)$, except two field populations (\# 1 and 6) where SR value was 4.66 and 14.6, respectively. In fact, we found that the DEF synergist reduced resistance to temephos in the two populations, where the resistance ratios were reduced from 624 to 263.87 and 14.6 to 2.2 at $\mathrm{LD}_{50}$ in samples \# 1 and 6 , respectively. These decrease of resistance level confirmed the important role played by esterases on the enzymatic detoxification of these two strains. The results with $\mathrm{Pb}$ indicated that oxydases were not involved in temephos resistance of $A n$. labranchiae, as detected by the lower SR values in all strains $(0.81<\mathrm{SR}<1.77)$.

\section{Cross-resistance Temephos/Propoxur}

We found that mortality caused by propoxur varied from 2\% in samples \# 1 showing the highest resistance levels to studied temephos insecticide $\left(624\right.$ at $\left.\mathrm{LC}_{50}\right)$ to $73 \%$ in sample \# 3 showing the lowest resistance $\left(6.2\right.$ at $\left.\mathrm{LC}_{50}\right)$. A strong correlation between the mortality due to propoxur and the $\mathrm{LC}_{50}$ of temephos (Spearman rank correlation, $(r)=-0.72(\mathrm{P}<0.01))$ was registered. These results indicated that the insensitive AChE 1 had a major role in the recorded resistance to temephos.

\section{Discussion}

The finding that the majority of field populations showed low, moderate, and high resistance ratios $(6.2<\mathrm{RR} 50<$ $624)$ to temephos are similar to those obtained by previous studies realized in Tunisia with other mosquitoes species $^{4,16,17}$ but never on Anopheles mosquitoes. Ben Cheilkh et $\mathrm{al}^{4}$ showed that field populations of Culex pipiens larvae from Tunisia were less resistant to temephos not exceeding 10 -folds. Recently, other authors ${ }^{18}$ from the same country reported high resistance with RR50 of 440-folds. Our finding is surprising because temephos insecticide was not the principle larvicide used in Tunisia for successful interruption of autochthonous malaria transmission. These findings should be confirmed by more studies for temephos insecticide on more larval population collected from the same areas.

Resistance of $A n$. labranchiae to temephos has previously studied in Morocco country ${ }^{1}$. Authors found low resis- tance to this larvicide in sentinel site. Study on An. stephensi in Oman country ${ }^{19}$ showed moderate resistance to temephos. In India, This species has been reported susceptible ${ }^{20,21}$ with $\mathrm{LC}_{50}$ range of 0.008-0.015. Despite the minor use of temephos insecticide in last years but study areas are known by their agricultural activities and farmers use frequently organophosphate insecticides to control pests. These activities can affect the susceptibility status of $A n$. labranchiae that's why integrated vector management in public health must take into consideration the integrated pest management in agriculture as a priority to limit vector/pests resistance to pesticides.

Our results showed that all tested populations are resistant to temephos despite there are no national program based on temephos insecticide to control this species. In fact, the department of hygiene and environmental protection gives priority to biological (larvivorous fishes) and environmental control. Knowing that waters are the mosquitoes breeding habitat and there are many sources of water contamination, including naturally occurring chemicals and minerals, this species may have developed resistance to these compounds to save itself.

Our results showed that esterases were not associated with resistance in the majority of field populations tested $(r=-0.009, p>0.05)$. Similar results were found by Selvi et $\mathrm{al}^{22}$ in larvae and adults of different species mosquitoes. On the other hand, a strong correlation between esterase activity and resistance to temephos were reported by many authors in Tunisia and other countries ${ }^{23-26}$. Any correlation between oxidases activity and RR50 values of temephos obtained from bioassay $(\mathrm{r}=0.190, \mathrm{p}>0.05)$ were detected in our findings. Similar results were found by Paeporn et $\mathrm{al}^{27}$. However, The CYP450 enzyme was associated with temephos resistance in previous studies of Ben Cheikh et $\mathrm{al}^{4}$. and Bisset et $\mathrm{al}^{28}$.

A strong correlation between the mortality due to propoxur and the $\mathrm{LC}_{50}$ of temephos (Spearman rank correlation, $(r)=-0.72(\mathrm{P}<0.01))$ was registered indicating that insensitive AChE 1 play a clear role in temephos resistance as reported by Macoris et $\mathrm{al}^{28}$ and Saelim et $\mathrm{al}^{30}$. It should be noted that AChE 1 has been well documented as a resistance mechanism of organophosphate and carbamate insecticides in mosquito populations by Hemingway et $\mathrm{al}^{30}$. Raymond et $\mathrm{al}^{32}$ and Cui et $\mathrm{al}^{33}$. 


\section{Conclusion}

Our study shows for the first time in Tunisia the resistance status of $A n$. labranchiae to temephos insecticide. The resistance ratios of this species were higher than recorded in other countries. Biochemical and molecular studies would be of great importance to identify the mechanisms involved in resistance to temephos.

\section{Acknowledgments}

We are grateful to the Regional Directories of Public Health. A special thanks to Dr. S. Fessi, Dr. A. Houerbi, Dr. L. Sakhri, Dr. T. Barhoumi, Mrs. S. Kilani, H. Hajlaoui, A. Mribai, H. Dellaii, H. Aloui, A. Rezeigui, N. Mejri, S. Ben Bdira for their previous help and effort to identify breeding sites of Anopheles mosquitoes in Northern and Central Tunisia.

\section{Conflict of interest}

The authors declare that they have no conflict of interest.

\section{References}

1. Faraj C, Adlaoui E, Ouahabi S, Rhajaoui M, Fontenille D, Lyagoubi M. Entomological investigations in the region of the last malaria focus in Morocco. Acta Tropical 2009, 109 (1) : 70-73.

2. Kooli J, Rhaiem A. Sensibilité des larves de moustiques aux insecticides dans la région de Tunis en 1984. Arch Inst Pasteur Tunis 1989, 66 : 61-71.

3. Ben Cheikh H, Marrakchi M, Pasteur N. Mise en évidence d'une très forte résistance au chlorpyrifos et à la perméthrine chez les moustiques Culex pipiens de Tunisie. Arch Inst Pasteur Tunis 1995, 72: 7-12.

4. Ben Cheikh H, Haouas-Ben Ali Z, Marquine M, Pasteur N.Resistance to organophosphorus and pyrethroid insecticides in Culex pipiens (Diptera: Culicidae) from Tunisia. J Med Entomol 1998, 35: 251-260.

5. Pasteur N, Marquine M, Ben Cheikh H, Bernard C, Bourguet D. A new mechanism conferring unprecedented high resistance to chlorpyrifos in Culex pipiens (Diptera : Culicidae). J Med Entomol 1999, 36: 794-802.

6. WHO. Pesticides and their application for the control of vectors and pests of public health importance. Geneva: World Health Organization 2006.

7. WHO, "Vector resistance to pesticides," 15th report of the WHO Expert Committee on Vector Biology and
Control, Technical Report Series 818, WHO, Geneva, Switzerland, 1992.

8. Romi R. Anopheles labranchiae, an important malaria vector in Italy, and other potential malaria vectors in Southern Europe. European Mosquito Bulletin 1999, 4: 8-10.

9. Toty C, Barré H, Le Goff G, Larget-Thiéry I, Rahola N, Couret D, Fontenille D. Malaria risk in Corsica, former hot spot of malaria in France. Malaria Journal 2010, 9: 1.

10. Chahed M, Bouratbine A, Krida G, Ben Hamida A. Réceptivité de la Tunisie au paludisme après son eradication: Analyse de la situation pour une adéquation de la surveillance. Bulletin de la Société de Pathologie Exotique 2001, 94(3) : 271-276.

11. Hammadi D, Boubidi SC, Chaib SE, Saber A, Khechache Y, Gasmi M, Harrat Z. Le paludisme au Sahara algérien. Bulletin de la Societe de Pathologie Exotique 2009, 102(3) : 185-192.

12. Brunhes J, Rhaim A, Geoffroy B, Angel G, Hervy JP. Les moustiques de l'Afrique me'diterrane'enne CDROM d'identification et d'enseignement, Edition IRD, Montpellier, France. 1999.

13. Raymond M, Fournier D, Bride JM, Cuany A, Bergé J, Magnin M, Pasteur N. Identification of resistance mechanisms in Culex pipiens(Diptera: Culicidae) from southern France: insensitive acetylchlinesterase and detoxifying oxidases. J Econ Entomol 1986, 79: 1452-1458.

14. Raymond M, Prato G, Ratsira D. PROBIT. Analysis of mortality assays displaying quantal response. Praxeme (Licence No. L93019), Saint Georges d'Orques, France. 1993.

15. Finney DJ. Probit analysis. Cambridge University Press, Combridge. 1971.

16. Daaboub J, Tabbabi A, Lamari A, Feriani M, Boubaker C, et al. Temephos Resistance in Three Populations of Culex pipiens Collected from Three Districts of Southern Tunisia and Its Significance for the Resistance Mechanism. Vector Biol J 2017, 2:1.

17. Tabbabi A, Daaboub J, Lamari A, Ben Cheikh R, Ben Jha I, Ben Cheikh H. Susceptibility of different geographical strains of culex pipiens (diptera: culicidae) to temephos in grand Tunis area of Tunisia. International Journal of Multidisciplinary and Development 2017, 4(7): 327-330.

18. Daaboub J, Tabbabi A, Lamari A, Ben Cheikh R, Ben Haj Ayed A, Ben Cheikh H. Susceptibility of field-collected mosquitoes (Culex pipiens) in Northern Tunisia to 
temephos, an organophosphate insecticide. Asian Pac. J. Health Sci 2017, 4(2):157-161.

19. Parvez SD, Al-Wahaibi SS. Comparison of three larviciding options for malaria vector control. Eastern Mediterr Health J 2003, 9: 627-636.

20. Tikar SN, Mendki MJ, Sharma AK, Sukumaran D, Veer V, Parashar BD. Resistance status of the malaria vector mosquitoes, Anopheles stephensi and Anopheles subpictus towards adulticides and larvicides in arid and semi-arid areas of India. J Insect Sci 2011, 11 (85): 1-10.

21. Singh PK, Mittal PK, Kumar G, Dhiman RC. Insecticide susceptibility status of Aedes aegypti and Anopheles stephensi larvae against temephos in Delhi, India. Int J Mosq Res 2014, 1(3): 69-73.

22. Selvi S. Comparison of esterases between life stages and sexes of resistant and susceptible strains of vector mosquitoes. 2009; M.Sc. Thesis, University of Malaya.

23. Kao LR, Motoyama N, Dauterman WC. The purification and characterization of esterases from insecticide resistant and susceptible houseflies. Pesticide Biochemistry and Physiology 1985, 23: 228-239.

24. Yan PC, Sudderuddin KI. Toxicology studies of insecticides on Culex quinquefasciatus (Say) and Aedes aegypti (L.). Southeast Asian Journal of Tropical Medicine and Public Health 1978, 9(3): 378-383.

25. Chen CD, Nazni WA, Lee HL, Seleena B, Sofian-Azirun M. Biochemical detection of temephos resistance in $A e^{-}$ des (Stegomyia) aegypti (Linnaeus) from dengue-endemic areas of Selangor State, Malaysia. Proceeding of the $3^{\text {rd }}$ ASEAN Congress of Tropical Medicine and Parasitology 2008. pp. $6-20$.

26. Ben Cheikh R, Berticat C, Berthomieu A, Ben Cheikh $\mathrm{H}$, Weill M. Characterization of a novel high-activityesterase in Tunisian populations of Culexpipiens. J Econ Entomol 2008, 101: 481-91.
27. Paeporn P, Komalamisra N, Deesin V, Rongsriyam Y, Eshita Y, Thongrungkiat S. Temephos resistance in two forms of Aedes aegypti and its significance for the resistance mechanism. Southeast Asian Journal of Tropical Medicine and Public Health 2003, 99:12-21.

28. Bisset JA, Rodriguez MM, Diaz C, Soca A. Course of insecticide resistance in Culex quinquefasciatus (Diptera: Culicidae) in a region of La Habana. Rev Cubana Med Trop 2000, 52: 180-185.

29. Macoris L, Andrighetti MT, Takaku L, Glasser CM, Garbeloto VC, Bracco JE. Resistance of Aedes aegypti from the State of Sao Paulo, Brazil to organophosphates insecticides. Memorias do Instituto Oswaldo Cruz 2003, 98(5): 703-708.

30. Saelim V, Brogdon WG, Rojanapremsuk J, Suvannadabba S, Pandii W, Jones JW, Sithiprasasna R. Bottle and biochemical assays on temephos resistance in Aedes aegypti in Thailand. Southeast Asian Journal of Tropical Medicine and Public Health 2005, 36(2): 417- 425.

31. Hemingway J, Smith C, Jayawardena KG, Herath PRJ. Field and laboratory detection of the altered acetylcholinesterase resistance genes which confer organophosphate and carbamate resistance in mosquitoes (Diptera: Culicidae). Bulletin of Entomological Research 1986, 76: 559-565. 32. Raymond M, Fournier D, Berge J, Cuany A, Bride JM, Pasteur N. Single mosquito test to determine genotypes with an acetylcholinesterase insensitive to inhibition to propoxur insecticide. Journal of American Mosquito Control Association. 1985, 1: 425-427.

33. Cui F, Raymond M, Berthomieu A, Alout H, Weill M, Qiao CL. Recent emergence of insensitive acetylcholinesterase in Chinese populations of Culex pipiens (Diptera: Culicidae). Journal of Medical Entomology. 2006, 43: 879-883. 